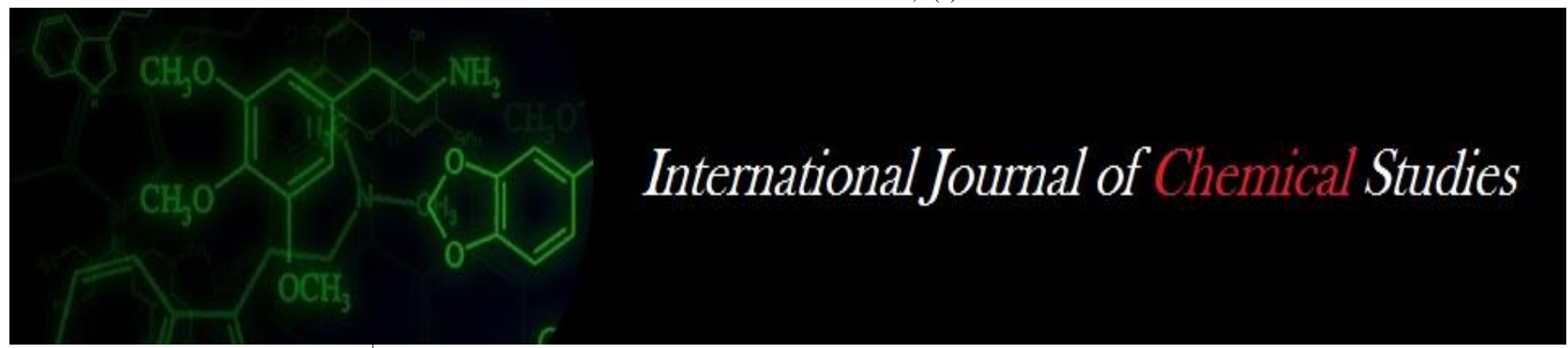

P-ISSN: 2349-8528

E-ISSN: 2321-4902

www.chemijournal.com

IJCS 2020; 8(4): 3237-3239

(C) 2020 IJCS

Received: 26-05-2020

Accepted: 27-06-2020

\section{AB Gosavi}

Agricultural Research Station,

Niphad, District Nashik,

Maharashtra, India

\section{SS Dodake}

Agricultural Research Station,

Niphad, District Nashik,

Maharashtra, India

\section{AP Padhye}

Agricultural Research Station,

Niphad, District Nashik,

Maharashtra, India
Corresponding Author:

AB Gosavi

Agricultural Research Station,

Niphad, District Nashik,

Maharashtra, India

\section{Assessing nutrient requirement of wheat under maize-wheat cropping sequence}

\author{
AB Gosavi, SS Dodake and AP Padhye
}

DOI: https://doi.org/10.22271/chemi.2020.v8.i4an.10153

\begin{abstract}
In order to assess the nutrient requirement of wheat after grain maize was conducted at Agricultural Research Station, Niphad, Dist. Nashik, Maharashtra during 2014-15 to 2016-17. During kharif season, maize (cv. Rajeshree) for grain purpose was sown by applying of recommended dose of fertilizers (120:60:40 N: $\mathrm{P}_{2} \mathrm{O}_{5}: \mathrm{K}_{2} \mathrm{O} \mathrm{kg} \mathrm{ha-1}$ ). In rabi season wheat crop was sown with five treatments viz. absolute control, recommended dose of fertilizers (120:60:40 N:P $\left.\mathrm{P}_{5}: \mathrm{K}_{2} \mathrm{O} \mathrm{kg} \mathrm{ha}+\mathrm{FYM} 10 \mathrm{t} \mathrm{ha}^{-1}\right)$, fertilizer application as per soil test basis, 125 per cent of recommended dose of fertilizers and 150 per cent of recommended dose of fertilizers. The pooled results of three years experiment revealed that application of 150 per cent of recommended dose of fertilizers to wheat crop produced significantly higher grain $\left(40.28 \mathrm{q} \mathrm{ha}^{-1}\right)$ and straw (55.50 $\left.\mathrm{q} \mathrm{ha}^{-1}\right)$ yields over absolute control. It was at par with the treatment application of 125 per cent of recommended dose of fertilizers $\left(38.27 \mathrm{q} \mathrm{ha}^{-1}\right)$ and fertilizer application as per soil test basis $\left(37.44 \mathrm{q} \mathrm{ha}^{-1}\right)$. The soil available major nutrients viz. nitrogen, phosphorus and potassium, after harvest of wheat, were observed higher in the treatment of 150 per cent of recommended dose of fertilizers compared to initial status of the soil.
\end{abstract}

Keywords: Maize, wheat, nutrient requirement

\section{Introduction}

As maize has wide adaptability and compatibility under diverse soil and climatic conditions, it is cultivated in sequence with different crops under various agro-ecologies of the country. Hence, it is considered as one of the potential driver of crop diversification under different situation. Among different maize based cropping systems, maize-wheat ranks $1^{\text {st }}$ having $1.8 \mathrm{~m}$ ha area mainly concentrated in rainfed ecologies. Maize-wheat is the $3^{\text {rd }}$ most important cropping systems after rice-wheat and rice-rice that contributes about 3 per cent in the national food basket. As it is universally known that maize is the heavy feeder crop, the nutrient management of such crop is very essential under sole cropping or in cropping system. As a result of its negligence, most of the productive soils are becoming unproductive. Imbalanced fertilization is one of the important factor limiting crop yields. Problem is more severe in acid soils which are under continuous cropping (Prasad et al., 2010) ${ }^{[6]}$ Hence, to assess the nutrient requirement of wheat after grain maize the present experiment was conducted.

\section{Materials and Methods}

Three cycles of maize-wheat cropping sequence were conducted with fertilizer management at Agricultural Research Station, Niphad, Dist. Nasik (MS) during 2014-15 to 2016-17. Maize was taken as a general crop in kharif season and for subsequent wheat crop in rabi, five treatments as absolute control, recommended dose of fertilizers, fertilizer application as per soil test basis, 125 per cent of RDF and 150 per cent of RDF were given. The experiment was laid out in randomised block design with four replications. The soil of the experimental site was clayey in texture having $\mathrm{pH} 8.24, \mathrm{EC} 0.41 \mathrm{dSm}^{-1}$, medium in organic carbon $(0.51 \%)$, medium in nitrogen $\left(278 \mathrm{~kg} \mathrm{ha}^{-1}\right)$, medium in phosphorous (18.17 $\left.\mathrm{kg} \mathrm{ha}^{-1}\right)$ and high in potassium (471 kg ha-1). Soil samples before and after harvest of each crop were collected and analyzed for major and micronutrients using standard procedures. 


\section{Results and Discussion}

The pooled results from Table 1 revealed that the grain and straw yields were influenced significantly due to different treatments of fertilizer. Fertilizer application @ 150 per cent (180:90:60 N: $\left.\mathrm{P}_{2} \mathrm{O}_{5}: \mathrm{K}_{2} \mathrm{O} \mathrm{kg} \mathrm{ha}{ }^{-1}\right)$ of the recommended dose of fertilizers produced significantly higher grain $\left(40.28 \mathrm{q} \mathrm{ha}^{-1}\right)$ and straw $\left(55.50 \mathrm{q} \mathrm{ha}^{-1}\right)$ yields over absolute control (zero fertilizers) and recommended dose of fertilizers. It was at par with the treatments of fertilizer application as per soil test (180:60:20 N: $\mathrm{P}_{2} \mathrm{O}_{5}: \mathrm{K}_{2} \mathrm{O} \mathrm{kg} \mathrm{ha}{ }^{-1}$ ) and 125 per cent of RDF (150:75:50 N: $\mathrm{P}_{2} \mathrm{O}_{5}: \mathrm{K}_{2} \mathrm{O} \mathrm{kg} \mathrm{ha-1).} \mathrm{Sharma} \mathrm{et} \mathrm{al} \mathrm{(2014)}{ }^{[7]}$ reported the results on effect of three decade long term application of chemical fertilizers and amendments on the yield of continuous maize-wheat crop rotation in an acid alfisol at Palampur revealed that continuous omission of essential nutrients in a maize-wheat sequence resulted in an appreciable decline in the grain yield of maize and wheat crops. A remarkable reduction in crop yield was noticed in plots where nitrogen was applied alone. Use of recommended level of $\mathrm{N}$ alone through urea had deleterious effect on crop productivity. The continuous exhaustion of native pools of $\mathrm{K}$ in 100 per cent NP treated plots appreciably reduced percent grain yield. Application of farmyard manure (FYM) and lime along with NPK fertilizers increased the crop yield.

The integrated use of optimal dose of NPK and FYM give better and more sustainable yields. Hadda and Arora (2006) ${ }^{[3]}$ reported that significant increase in grain yield of wheat was observed with the application of different soil and nutrient management practices over the farmers' practice with a maximum of 34 per cent. Soil moisture storage increased by $12,30,35$ and 45 per cent with shallow tillage, deep tillage, recommended dose of fertilizers (RDF, 75\%) + FYM and raised-bed sowing, respectively compared with the farmers' practice. Raised-bed sowing, RDF (100\%), RDF (75\%) + FYM and deep tillage showed an increase of 52, 55, 57 and 37 per cent, respectively in height of maize plant over the farmers' practice at 60 days after sowing.

The soil analysis after harvest of wheat (Table 2) reveled that, application of fertilizers @ 150 per cent of $\operatorname{RDF}\left(\mathrm{T}_{5}\right)$ significantly improved the $\mathrm{N}, \mathrm{P}$ and $\mathrm{K}$ content of the soil. Whereas, soil available nutrients in other treatments were also improved over initial soil status due to different levels of fertilizer application except absolute control. Naresh et al (2014) ${ }^{[4]}$ observed that there was no significant increase in yield of maize beyond $120 \mathrm{~kg} \mathrm{~N} \mathrm{ha-1}$. Sole maize-wheat rotation showed a decline in soil organic carbon by 3.7 per cent, while black gram and cowpea intercropping with maize in paired rows (2:2 row ratio) followed by wheat had increased contents of per cent organic carbon in soil as 0.63 and 0.67 , respectively, as compared to initial values of 0.54 per cent. Plots treated with intercrops/farm yard manure (FYM) during the rainy season sustained the wheat yield while the control plot showed a decline in wheat yield by 4-9 per cent. Prasad et al (2010) ${ }^{[6]}$ reported that maximum N, P and $\mathrm{K}$ uptake values were recorded when 50 per cent $\mathrm{N}$ was substituted by FYM in maize $\left(114.6,23.9\right.$ and $\left.125.5 \mathrm{~kg} \mathrm{ha}^{-1}\right)$ and wheat $\left(99.7,18.1\right.$ and $89.8 \mathrm{~kg} \mathrm{ha}^{-1}$ ) and maize-wheat system $\left(214.3,42.0\right.$ and $\left.215.3 \mathrm{~kg} \mathrm{ha}^{-1}\right)$ followed by $25 \% \mathrm{~N}$ through FYM and remaining through inorganic source and minimum in control. The productivity, nutrient uptake and per cent response increased with the increase in the fertilizer level but the reverse trend was noted in case of agronomic efficiency and apparent $\mathrm{N}$ recovery per cent.

The data on nutrient uptake of the wheat (Table 3) revealed the significant difference in major nutrient uptake was recorded due to different fertilizer treatments. The application of 150 per cent recommended dose of fertilizer significantly improved nitrogen $\left(145.36 \mathrm{~kg} \mathrm{ha}^{-1}\right)$, phosphorus $(38.45 \mathrm{~kg}$ ha$\left.{ }^{1}\right)$ and potassium $\left(228.55 \mathrm{~kg} \mathrm{ha}^{-1}\right)$. It might be due to balanced and fair supply of the essential elements which might have facilitated utilization of assimilates towards synthesis of high molecular weight compounds like amino acids, proteins and nucleic acids etc. thereby maintaining a continuous demand for carbon assimilation. Favorable effect of fertilizer application on nitrogen in wheat has also been reported by Behera and Singh (2009) ${ }^{[1]}$, Dwivedi et al., (2017) ${ }^{[2]}$. The economics of wheat (Table 4) was influenced due to different fertilizer treatments. Significantly higher gross returns (Rs.85213 ha-1) was observed in the treatment where 150 per cent of RDF was applied which was at par with 125 per cent of RDF (Rs. 80837) and AST (Rs. 79282).

However the higher $\mathrm{B}: \mathrm{C}$ ratio $(1: 2.45)$ was observed in the control treatment since no fertilizers were applied to it. This was followed by the treatment application of 125 per cent fertilizers $\left(\mathrm{T}_{4}\right)(1: 2.42)$ and 150 per cent of the RDF $\left(\mathrm{T}_{5}\right)$ (1:2.35). Sharma et al. (2015) ${ }^{[8]}$ reported that application of recommended dose of NPK resulted in significantly higher grain yield of maize and wheat, maize equivalent yield, gross return and net return over rest of the treatments. Recommended NPK resulted in 85 per cent and 53 per cent higher maize grain equivalent yield and Rs 30150 and Rs 24626 more net return over control and recommended $\mathrm{N}$, respectively. The response in terms of $\mathrm{kg}$ grain per $\mathrm{kg}$ of nutrient applied was higher for applied phosphorus $(20.85 \mathrm{~kg}$ maize grain equivalent) followed by potash (19.19) and nitrogen (5.69).

Table 1: Grain, straw yields, thousand grain weight of wheat

\begin{tabular}{|c|c|c|c|c|c|c|c|c|}
\hline \multirow{3}{*}{ Treatment } & \multicolumn{2}{|c|}{ 2014-15 } & \multicolumn{2}{|c|}{ 2015-16 } & \multicolumn{2}{|c|}{ 2016-17 } & \multicolumn{2}{|c|}{ Mean } \\
\hline & \multicolumn{8}{|c|}{ Grain|StrawGrainStraw Grain|Straw Grain|Straw } \\
\hline & \multicolumn{8}{|c|}{$\left(\mathbf{q ~ h a}^{-1}\right)$} \\
\hline 1. C & 21.67 & 29.28 & 20.19 & 32.39 & 14.33 & 20.94 & 18.73 & 27.54 \\
\hline 2. GRDF & 29.88 & 41.56 & 28.89 & 42.64 & 36.10 & 47.68 & 31.62 & 43.96 \\
\hline 3. AST & 35.82 & 51.70 & 35.57 & 52.62 & 40.94 & 56.29 & 37.44 & 53.54 \\
\hline $125 \%$ of $\mathrm{RDF}$ & 36.96 & 50.23 & 36.01 & 51.56 & 41.85 & 55.14 & 38.27 & 52.31 \\
\hline $150 \%$ of $\mathrm{R}$ & 37.19 & 52.14 & 39.61 & 57.28 & 44.03 & 57.09 & 40.28 & 55.50 \\
\hline & 1.71 & 1.86 & 2.55 & 2.83 & 1.86 & 2.04 & 0.94 & 1.54 \\
\hline $\mathrm{CD}$ at $5 \%$ & 5.27 & 5.75 & 7.86 & 8.75 & 5.74 & 6.28 & 2.91 & 4.75 \\
\hline
\end{tabular}

Table 2: Soil analysis data after harvest of wheat

\begin{tabular}{|c|c|c|c|c|c|}
\hline \multirow{2}{*}{ Treatment } & $\mathbf{p H}$ & $\mathbf{E C}$ & $\mathbf{N}$ & $\mathbf{P}$ & $\mathbf{K}$ \\
\cline { 2 - 6 } & - & $\left.\mathbf{( d S m}^{-1}\right)$ & \multicolumn{3}{|c|}{$\left.\mathbf{( k g ~ h a}^{-\mathbf{1}}\right)$} \\
\hline Initial & $\mathbf{7 . 6 9}$ & $\mathbf{0 . 4 4}$ & $\mathbf{1 5 2 . 3 5}$ & $\mathbf{2 1 . 7 7}$ & $\mathbf{4 5 2}$ \\
\hline 1. Control & 7.67 & 0.53 & 127.41 & 17.84 & 375 \\
\hline 2. GRDF & 7.74 & 0.51 & 162.61 & 23.44 & 427 \\
\hline 3. AST & 7.74 & 0.44 & 177.78 & 28.66 & 465 \\
\hline 4. 125\% of RDF & 7.75 & 0.43 & 197.72 & 32.86 & 490 \\
\hline 5. 150\% of RDF & 7.74 & 0.44 & 202.06 & 34.65 & 487 \\
\hline SE \pm & - & - & 6.23 & 1.15 & 10.21 \\
\hline CD at5\% & - & - & 19.22 & 3.57 & 31.48 \\
\hline
\end{tabular}

Table 3: Uptake of nutrients by wheat (Pooled mean of 3 years)

\begin{tabular}{|c|c|c|c|}
\hline Treatments & $\begin{array}{c}\mathbf{N} \\
\left(\mathbf{k g ~ h a}^{-1}\right)\end{array}$ & $\begin{array}{c}\mathbf{P} \\
\left(\mathbf{k g ~ h a}^{-1}\right)\end{array}$ & $\begin{array}{c}\mathbf{K} \\
\left(\mathbf{k g ~ h a}^{-1}\right)\end{array}$ \\
\hline 1. Control & 70.24 & 18.36 & 196.54 \\
\hline 2. GRDF & 135.98 & 33.26 & 265.14 \\
\hline 3. AST & 128.20 & 28.51 & 210.20 \\
\hline 4. 125\% of RDF & 142.56 & 33.65 & 226.54 \\
\hline 5. 150\% of RDF & 145.36 & 38.45 & 228.55 \\
\hline SE \pm CD 5\% & 5.83 & 1.72 & 6.18 \\
\hline & 17.99 & 5.26 & 19.07 \\
\hline
\end{tabular}


Table 4: Economics of wheat

\begin{tabular}{|c|c|c|c|c|c|c|}
\hline \multirow{2}{*}{ Treatment } & \multicolumn{2}{|c|}{$\begin{array}{c}\text { Yields } \\
\left(\mathbf{q} \mathbf{~ h a}^{-1}\right)\end{array}$} & $\begin{array}{c}\text { Cost of } \\
\text { cultivation }\end{array}$ & $\begin{array}{c}\text { Gross } \\
\text { returns }\end{array}$ & $\begin{array}{c}\text { Net } \\
\text { returns }\end{array}$ & $\begin{array}{c}\text { B:C } \\
\text { ratio }\end{array}$ \\
\cline { 2 - 7 } Grain $^{\text {Straw }}$ & \multicolumn{3}{|c|}{$\left(\right.$ Rs ha $\left.^{-1}\right)$} & & \\
\hline 1. Control & 18.73 & 27.54 & 15306 & 36681 & 21375 & 2.45 \\
\hline 2. GRDF & 31.62 & 43.96 & 33381 & 67009 & 33629 & 2.00 \\
\hline 3. AST & 37.44 & 53.54 & 33888 & 79282 & 45394 & 2.34 \\
\hline 4. 125\% of RDF & 38.27 & 52.31 & 34483 & 80837 & 46354 & 2.42 \\
\hline 5. 150\% of RDF & 40.28 & 55.50 & 35584 & 85213 & 49629 & 2.35 \\
\hline SE \pm & 0.94 & 1.54 & - & 3540 & 2967 & - \\
\hline CD at5\% & 2.91 & 4.75 & - & 9487 & 9150 & - \\
\hline
\end{tabular}

\section{Conclusion}

From the results of the above experiment, it is concluded that application of 150 per cent of general recommended dose of fertilizers to wheat crop after grain maize crop produces higher grain and straw yields over absolute control. Also the ancillary characters like thousand grain weight and number of grains per earhead are improved due to application of 150 per cent of general recommended dose of fertilizers for wheat crop.

\section{References}

1. Behera SK, Singh D. Effect of 31 years of continuous cropping and fertilizer use on soil properties and uptake of micronutrient by maize (Zea mays L.)-wheat (Triticumastivum L.) system, Journal of Agricultural Science 79: 264-270. Biophys. Acta. 2009; 1763:595608.

2. Dwivedi Ashish, Rana NS, Naresh RK, Dhyani BP, Singh Adesh, Shahi UP. Effect of Nutrient Management strategies and sources of Nutrient on yield and Nutrient uptake in Wheat under subtropical conditions, Bull. Env. Pharmacol. Life Sci. 2017; 6(110):101-107.

3. Hadda MS, Arora S. Soil and nutrient management practices for sustaining crop yields under maize-wheat cropping sequence in sub-mountain Punjab, India. Soil \& Environ. 2006; 25(1):1-5.

4. Naresh RK, Tomar SS, Shahi UP, Singh SP, Purushottam, Singh B et al. Sustainability of maizewheat cropping system by different legume intercropping and nitrogen level treatments on light distribution, soil temperature and rop productivity. African Journal of Plant Science. 2014; 8(4):204-213

5. Pandey PR, Pandey H, Nakagawa M. Assessment of Rice and Maize Based Cropping Systems for Rural Livelihood Improvement in Nepal. The Journal of Agriculture and Environment 10, Jun.2009 Technical Paper, 2009, 57.

6. Prasad J, Karmakar S, Kumar R, Mishra B. Influence of Integrated Nutrient Management on Yield and Soil Properties in Maize-Wheat Cropping System in an Alfisol of Jharkhand. Journal of the Indian Society of Soil Science. 2010; 58(2):200-204.

7. Sharma RP, Kaushal V, Verma G, Sharma SP. Effect of three decade long application of chemical fertilizer and amendments on crop yield under maize - wheat cropping system in an acid alfisol. Journal of Applied and Natural Science. 2014; 6(1):106-109

8. Sharma SK, Rana SS, Subehia SK. Response of maize wheat cropping system to NPK in low hills of Himachal Pradesh. Himachal Journal of Agricultural Research. 2015; 41(1):73-76. 